\title{
Adaptation of the Edinburgh Postnatal Depression Scale in the Indonesian Version: Self-reported Anxiety and Depression Symptoms in Pregnant Women
}

\author{
Dewi Nirmala Sari ${ }^{1,2 *}$ (D) ${\text { Hervita } \text { Diatri }^{3} \text { (D) } \text { Kemal Siregar }^{4} \text { (D), Hadi Pratomo }}^{4}$ (D) \\ ${ }^{1}$ Doctoral Program, Faculty of Public Health, Universitas Indonesia, Jakarta, Indonesia; ${ }^{2}$ Department of Midwifery, Health \\ Polytechnic Jakarta III, Ministry of Health Republic of Indonesia, Jakarta, Indonesia; ${ }^{3}$ Department of Psychiatry, Faculty of \\ Medical, Universitas Indonesia, Jakarta, Indonesia; ${ }^{4}$ Reproductive Health Study Group, Faculty of Public Health, Universitas \\ Indonesia, Jakarta, Indonesia
}

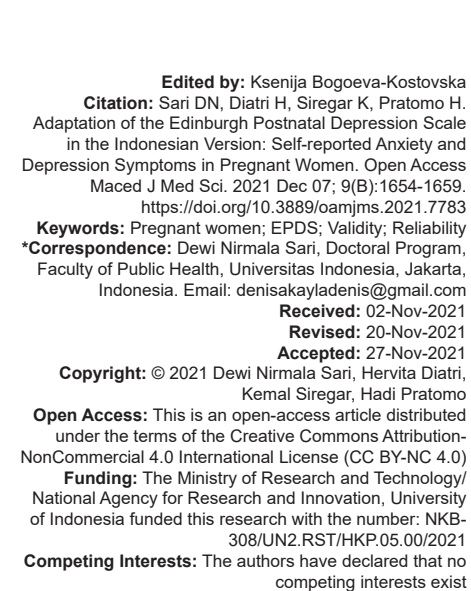

competing interests $\mathrm{n}$

\begin{abstract}
BACKGROUND: Anxiety and depression disorders in pregnant women are often not identified so that early treatment is not optimal. Indonesia already has comprehensive integrated antenatal care, including services for pregnant women with mental disorders, but until now Indonesia does not yet have a standardized instrument that is valid and suitable as a screening tool to assess symptoms of anxiety and depression in pregnant women. The Edinburgh Postnatal Depression Scale (EPDS) is a screening instrument with high sensitivity and specificity has been translated into Indonesian, but until now, the Indonesian version of the EPDS instrument has not been evaluated for validity and reliability in the population of pregnant women.

AIM: The purpose of this study was to adapt the Indonesian version of the EPDS instrument, including testing the validity and reliability of the instrument when used on pregnant women in Indonesia.

METHODS: This research was a cross-sectional study. The number of pregnant women participated was 125 samples. Data were collected randomly, and the assessment of symptoms of anxiety and depression was self-reported through online. Content validity was assessed with a content validity index from five experts, construct validation was analyzed by explanatory factor analysis, confirmatory factor analysis, and convergent validity. The reliability of the EPDS instrument was assessed by construct reliability and Cronbach's alpha.

RESULTS: Content validity index showed expert agreement with a value of 0.98 . The Indonesian version of the EPDS showed assessing three factors, namely: Depression (five items), anxiety (three items), and anhedonia (two items). The reliability of the Indonesian version of the EPDS instrument is good with Cronbach's alpha 0.80 and the internal reliability of the ten items (Cronbach's alpha 0.767-0.812).

CONCLUSION: The Indonesian version of the EPDS instrument is valid and reliable to be used to assess symptoms of anxiety and depression in pregnant women in antenatal care in Indonesia.
\end{abstract}

\section{Introduction}

Globally, the prevalence of anxiety disorders and depression in pregnant women is high in low- and middle-income countries, ranging from $1 \%$ to $37 \%$ [1], [2]. Pregnant women are estimated to experience anxiety disorders by $47.3 \%$ and depression by $59.7 \%$ in two regions of Indonesia (Yogyakarta and DKI Jakarta) [3], [4]. This can be an obstacle to improving maternal health and reducing a third of premature deaths related to mental health in the sustainable development goals (SDGs) targets in low- and middle-income countries, especially Indonesia [5]. The COVID-19 pandemic has also increased a challenge for improving mental health in pregnant women today [6].

Although various studies have described the high prevalence of mental health disorders in pregnant women, mental health services in pregnancy are still low in low- and middle-income countries. Health facilities have not been able to provide optimum services to detect symptoms of anxiety and depression in pregnant women so that about $50 \%-70 \%$ of pregnant women who have symptoms of anxiety disorders and/or depression are not identified in antenatal care [7], [8], [9]. This shows the high gap between the needs of pregnant women for mental health services and the availability of mental health services in antenatal care, especially the implementation of screening is still low in low- and middle-income countries, including Indonesia [10], [11].

The low ability of basic health facilities to screen for symptoms of anxiety and depression in pregnancy can be caused by many factors, including: Antenatal care standards are still more focused on the physical health of pregnant women, there is a misconception that anxiety and depression disorders are rare and can only be handled by specialists, lack of skills and low confidence in health workers to detect 
symptoms of anxiety, and depression in basic health facilities, as well as limited time and personnel of health workers [12], [13], [14], [15].

Indonesia already has an integrated service mechanism for pregnant women with mental disorders, but mental health screening has not yet become a standard for antenatal care and there is no standard instrument for assessing symptoms of anxiety and depression in pregnant women in Indonesia to date [16]. This will certainly hinder preventive and promotive efforts as well as early treatment of mental health in pregnancy. Therefore, it is necessary for us to get a valid instrument, suitable, and in accordance with Indonesian culture so that it can become a standard instrument in the screening program for symptoms of anxiety and depression in pregnant women in antenatal care at primary health facilities.

One of the strategies for providing valid, suitable, and appropriate instruments for Indonesian culture is to adapt the instruments to reduce bias and maximize the cultural validity of the selected instruments [17]. The Edinburgh Postnatal Depression Scale (EPDS) instrument was chosen because it has high sensitivity and specificity, is relatively easy and short to use, can be assessed by pregnant women themselves, and has been widely used in countries that have similar characteristics to Indonesia, and currently, the EPDS also not only used to assess symptoms of depression, but has been developed to assess symptoms of anxiety in pregnant women [18], [19], [20], [21].

The provision of a valid and appropriate assessment instrument for anxiety and depression symptoms is the first step of the four stages (readiness, recognition and prevention, response, and reporting and systems learning) that must be met for a country, such as Indonesia to be successful in implementing mental health services in maternal health services [22].

This study aimed to assess the validity and reliability of the Indonesian version of the EPDS instrument. The novelty of this research is to obtain a valid and reliable Indonesian version of the EPDS instrument to assess symptoms of anxiety and depression in pregnant women in Indonesia. The final results of this study are very useful as a basis for consideration for policy makers in maternal health and mental health programs to establish the Indonesian version of the EPDS instrument as a standard instrument in mental health services for pregnant women, especially in primary health facilities so as to improve mental health services in antenatal services.

\section{Methods}

This research was a cross-sectional study. Data were collected from the community of pregnant women living in the territory of Indonesia at random online with the distribution of Google forms, starting from 10 to 21 June 2021. The minimum number of pregnant women in this study is 120 samples with the provision of 12 pregnant women: One item of instrument. The inclusion criteria in this study were pregnant women who were not undergoing treatment for mental disorders, while the exclusion criteria were pregnant women who did not complete the data or did the assessment more than once.

Content validation assessment was carried out by five experts consisting of one psychiatrist, one obstetrician, two midwives, and one anthropologist who have work experience in their field an average of 24 years with a minimum of 16 years of work and a maximum of 35 years old.

The ethical approval in this study was obtained from the Ethics Commission of the Faculty of Public Health, University of Indonesia on October 21, 2020 with Nomor: Ket-627/UN2.F10.D11/PPM.00.02/2020.

EPDS instrument developed by Cox et al. (1987), consisted of ten questions that were assessed on a Likert scale of 0-3 [23]. In this study, the source of the translation of the Indonesian version of the EPDS instrument is from the Department of Health, Government of Western Australia (2006) which has obtained a translation copyright from The Royal College of Psychiatrists (1987) [24]. The Indonesian version of the EPDS instrument used in this study underwent several adjustments to the use of words according to the input from experts.

Data analysis carried out in this study includes:

a. Validity

Content validity index (CVI) to assess expert agreement on the relevance of the Indonesian version of the EPDS instrument item, explanatory factor analysis to identify instrument structure factors using principal component analysis (PCA) with varimax rotation, and confirmatory factor analysis (CFA) aims to validate the Indonesian version of the EPDS instrument, as well as convergent validity based on factor loading calculations to identify the convergence of observational variables that reflect the construct.

b. Reliability

Construct reliability to determine the percentage of total variance of latent variables explained by observational variables based on factor loading calculations and assessing internal consistency with Cronbach's alpha. 


\section{Results}

\section{Validity \\ Content validity}

The experts gave an assessment of the relevance of each item of the Indonesian version of the EPDS with a range of four Likert scales (one $=$ not relevant, two = less relevant, three $=$ quite relevant, and four = very relevant) [25]. The results of the analysis show that the experts agree that the Indonesian version of the EPDS instrument is relevant as a whole $(\mathrm{CVI}=0.98)$ and each item in the instrument (CV per item > 0.7) for assessing symptoms of anxiety and depression in pregnant women in Indonesia are shown in Table 1.

Table 1: Content validity index

\begin{tabular}{|c|c|c|c|c|c|c|c|}
\hline \multirow[t]{2}{*}{ Items } & \multicolumn{5}{|c|}{ Expert } & \multirow{2}{*}{$\begin{array}{l}\text { Number of } \\
\text { approvals }\end{array}$} & \multirow[t]{2}{*}{ CVI items } \\
\hline & 1 & 2 & 3 & 4 & 5 & & \\
\hline 1 & 4 & 4 & 4 & 4 & 4 & 5 & 1.00 \\
\hline 2 & 4 & 4 & 4 & 4 & 4 & 5 & 1.00 \\
\hline 3 & 4 & 3 & 4 & 4 & 3 & 5 & 1.00 \\
\hline 4 & 4 & 4 & 4 & 4 & 4 & 5 & 1.00 \\
\hline 5 & 4 & 4 & 4 & 4 & 4 & 5 & 1.00 \\
\hline 6 & 4 & 3 & 4 & 4 & 4 & 5 & 1.00 \\
\hline 7 & 4 & 3 & 4 & 4 & 4 & 5 & 1.00 \\
\hline 8 & 4 & 3 & 4 & 4 & 4 & 5 & 1.00 \\
\hline 9 & 4 & 3 & 4 & 4 & 4 & 5 & 1.00 \\
\hline 10 & 4 & 2 & 4 & 4 & 4 & 4 & 0.80 \\
\hline \multirow[t]{2}{*}{ Relevant proportion } & 1.00 & 0.90 & 1.00 & 1.00 & 1.00 & & \\
\hline & & & & & & CVI & 0.98 \\
\hline
\end{tabular}

\section{Construct validity}

After getting the EPDS instrument which was considered good by the experts, we tested the validity of the Indonesian version of the EPDS instrument. The number of pregnant women who self-assessed their feelings with the Indonesian version of the EPDS instrument through online was 133 people; eight pregnant women were excluded because they did the assessment more than twice. The characteristics of pregnant women in this study are described in Table 2.

Table 2: Characteristics of respondents $(n=125)$

\begin{tabular}{lll}
\hline Sample characteristics & Mean + SD & Proportion (\%) \\
\hline Age & $28.16+4.438$ & \\
Minimum & 20 years old \\
Maximum & 40 years old & \\
Education & & \\
SD & & 5.6 \\
Junior high school & & 11.2 \\
Senior High School & & 28.0 \\
PT & & 55.2 \\
Work & & 51.2 \\
Housewife & 49.8 \\
Work & $24.92+9.338$ & \\
Gestational Age & & 14.4 \\
0-12 weeks & & 45.6 \\
13-28 weeks & & 40.0 \\
29-39 weeks & & \\
\hline
\end{tabular}

\section{Explanatory factor analysis}

This study has sufficient sample data and there is a correlation between factor relationships so that it is feasible to continue factor analysis based on the KaiserMeyer-Olkin value $(=0.816)$, Barlett test of sphericity is significant $(p<0.05)$, measure sampling adequacy (MSA) for each item $>0.5$, and the communalities value for each item > 0.4 (Table 3).

Table 3: Measure sampling adequacy and communalities Indonesian version of EPDS items

\begin{tabular}{lll}
\hline Indonesian version of EPDS items & MSA & Communalities \\
\hline 1 & 0.801 & 0.537 \\
2 & 0.551 & 0.611 \\
3 & 0.834 & 0.562 \\
4 & 0.742 & 0.796 \\
5 & 0.807 & 0.628 \\
6 & 0.869 & 0.435 \\
7 & 0.791 & 0.696 \\
8 & 0.870 & 0.658 \\
9 & 0.845 & 0.638 \\
10 & 0.823 & 0.515 \\
\hline MSA: Measure sampling adequacy. & &
\end{tabular}

This study resulted in three structural factors of the Bahasa version of the EPDS that was formed with Eigenvalue $>1$ with a total variance explained of $60.76 \%$ in the population of pregnant women. The structural factors formed consist of depression factors (item 6 (things getting on top), 7 (sleep), 8 (sad), 9 (crying), and 10 (self-harm)), then anxiety factor (item 3 (self-harm). blame), 4 (anxious), and 5 (scared), and the last factor is anhedonia (items 1 (laugh) and 2 (enjoyment) (Table 4).

\section{CFA}

After getting three structural factors from the results of the EFA analysis, we performed a CFA to test the validity of the Indonesian version of the EPDS instrument used in the population of pregnant women. The results of this study indicate that the Indonesian version of the EPDS instrument is convergently valid for use in the population of pregnant women as indicated by the loading factor value of the ten items of Indonesian version of the EPDS are: $1(0.20), 2(0.30), 3(0.81)$, 4 (1.88), 5 (0.91), 6 (0.81), 7 (0.55), 8 (0.47), 9 (0.47), and $10(1.58)$ so that they have met the criteria $(>0.3)$ according to the Hairs (2014) [26]

Based on the loading factor value of the ten items of Indonesian version of the EPDS, the average variance extracted (AVE) value is obtained, namely, the depression factor (0.50), anxiety (0.52), and anhedonia $(0.81)$, the three factors have met the value $>0.5$ so that it can. It is concluded that the Indonesian version of the EPDS instrument is convergently valid for assessing symptoms of anxiety and depression in pregnant women in Indonesia [26].

\section{Reliability \\ Construct reliability}

The Indonesian version of the EPDS instrument is constructably reliable, based on the value of construct reliability calculated from the value of the loading factor per item, namely: Depression (0.77), anxiety (0.74), and anhedonia (0.84). 
Table 4: Explanatory factor structure of Indonesian version of EPDS

\begin{tabular}{|c|c|c|c|c|}
\hline EPDS Items & Indonesian version of EPDS's Items & Factor 1 "Depression" & Factor 2 "Anxiety" & Factor 3 "Anhedonia" \\
\hline 1 & Saya dapat tertawa dan melihat segi kelucuan hal-hal tertentu & & & 0.712 \\
\hline 2 & Saya menanti-nanti untuk melakukan sesuatu dengan penuh harapan & & & 0.781 \\
\hline 3 & $\begin{array}{l}\text { Saya menyalahkan diri sendiri jika ada } \\
\text { sesuatu yang tidak berjalan dengan baik }\end{array}$ & & 0.678 & \\
\hline 4 & $\begin{array}{l}\text { Saya merasa cemas atau khawatir tanpa } \\
\text { alasan }\end{array}$ & & 0.864 & \\
\hline 5 & Saya merasa takut atau panik tanpa alasan & 0.406 & 0.676 & \\
\hline 6 & Banyak hal menjadi beban untuk saya & 0.488 & 0.418 & \\
\hline 7 & Saya merasa begitu sedih sehingga sulit tidur & 0.764 & & \\
\hline 8 & Saya merasa sedih atau susah & 0.754 & & \\
\hline 9 & $\begin{array}{l}\text { Saya merasa sangat sedih sehingga saya } \\
\text { menangis }\end{array}$ & 0.757 & & \\
\hline 10 & $\begin{array}{l}\text { Pikiran untuk mencelakai diri sendiri sering } \\
\text { Muncul }\end{array}$ & 0.698 & & \\
\hline
\end{tabular}

\section{Internal consistency}

The Indonesian version of the EPDS instrument has good internal reliability. Cronbach's alpha $=0.80$. Cronbach's alpha if item deleted from ten items of Indonesian version of EPDS > 0.7, as follows: item 1 (0.807), 2 (0.812), 3 (0.793), 4 (0.784), 5 (0.768), 6 (0.777), 7 (0.767), 8 (0.769), 9 (0.771), and $10(0.793)$.

\section{Discussion}

This study aimed to assess the validity and reliability of the Indonesian version of the EPDS instrument used to assess symptoms of anxiety and depression in pregnant women in antenatal care in Indonesia. Our study found that the Indonesian version of the EPDS instrument has good validity and reliability, and can be used to assess symptoms of anxiety and depression in pregnant women in Indonesia.

The results of this study show that the CVI value of the Indonesian version of the EPDS instrument is 0.98 . This shows that experts agree and agree on the relevant Indonesian version of the EPDS instrument to assess symptoms of anxiety and depression in pregnant women in Indonesia, in accordance with the recommendations of Lynn (1986) in Tadjudin et al. (2017) which state that the CVI value received by a panel of experts who totaling five experts is $>0.83$ [27].

This study has a sufficient data set and is feasible for factor analysis. This study has the lowest Kaiser-Meyer-Olkin measure of sampling adequacy value on item $2(0.551)$ and the highest on item $8(0.870)$, a value of $>0.5$ (the value assigned to be able to perform factor analysis), and Bartlett's significant test of sphericity $(p<0.001)$ [26].

In this study, an explanatory factor analysis was conducted to identify the relationship between the manifest variables or indicators of the items in the Indonesian version of the EPDS to form a construct, considering that there has been no research on the structural factors of the Indonesian version of the EPDS instrument in the population of pregnant women, while the results of the previous research have shown that the structural factors formed on the EPDS instrument can be two or three structural factors with different indicator variables.

The results of this study using the principal component analysis (PCA) method and varimax rotation showed that there were three structural factors (depression, anxiety, and anhedonia) that correctly summarized the ten EPDS items. The results of this study are the same as the results of the previous studies (Coates, 2017; Odalovic, 2015; and Lee King, 2012) [28]. This shows that the Indonesian version of the EPDS instrument, which is usually used only to assess symptoms of depression, can also be used to assess symptoms of anxiety in pregnant women by maximizing analysis on the indicator variables that make up the anxiety factor, namely, items 3, 4, and 5 in accordance with the results of the previous studies $[20,29]$.

The results of this study also show that items 6-10 and items 3,4, and 5, as well as items 1 and 2 on the Indonesian version of the EPDS instrument have similar observations to form their respective constructs, described by the AVE value of the three factors $>0.5[26]$

The reliability test was carried out after ensuring that the ten items of the Indonesian version of the EPDS were valid. The results of this study illustrate that the indicators of the three structural factors formed in the Indonesian version of the EPDS instrument have good internal consistency $(C R>0.7)$ [26].

The assessment method for this EPDS instrument is a Likert scale with a range of values $0-3$. Therefore, Cronbach's alpha coefficient is the most appropriate method to test the consistency of the scale between items in this instrument. Cronbach's alpha values ranged from 0 to 1 with the following conditions: 0.0-0.4 (unreliable), 0.4-0.6 (less reliable), 0.6-0.8 (reliable), and $0.8-1$ (very reliable). The results of this study indicate that the Indonesian version of the EPDS instrument is reliable $(0.80)$ for use by pregnant women in Indonesia.

Hence, this study has identified that the Indonesian version of the EPDS instrument is valid and reliable for use in pregnant women, so it is feasible 
to conduct further research, namely, assessing the sensitivity and specificity of the Indonesian version of the EPDS instrument to assess symptoms of anxiety and depression in pregnant women in antenatal care.

\section{Conclusion}

The results of this study have shown that the Indonesian version of the EPDS instrument is valid and reliable to be used to assess symptoms of anxiety and depression in pregnant women in Indonesia. The Indonesian version of the EPDS instrument can be used as a standard instrument in antenatal care. This is very useful for the early detection and treatment of symptoms of anxiety and depression in pregnant women optimally.

\section{References}

1. Gelaye B, Rondon MB, Araya R, Williams MA. Epidemiology of maternal depression, risk factors and child outcomes in low-income and middle-income countries. Lancet Psychiatry. 2016;3(10):973-82. https://doi.org/10.1016/ S2215-0366(16)30284-X PMid:27650773

2. Jha S, Salve HR, Goswami K, Sagar R, Kant S. Burden of common mental disorders among pregnant women: A systematic review. Asian J Psychiatr. 2018;36:46-53. https:// doi.org/10.1016/j.ajp.2018.06.020

\section{PMid:29966886}

3. Misrawati, Afiyanti Y. Antenatal depression and its associated factors among pregnant women in Jakarta, Indonesia. Enferm Clin. 2020;30:96-101.

4. Hariyati NR, Raden A, Mawarti R, Tarigan M. Integrated antenatal care reduce childbirth anxiety among primigravida women. J Health Technol Assess Midwifery. 2019;2(1):33-9.

5. UNICEF. Roadmap of SDGs Indonesia: A Highlight. United States: UNICEF; 2017. p. 1-124. Available from: https://www. unicef.org/indonesia/media/1626/file/Roadmap of SDGs.pdf. [Last accessed on $2021 \mathrm{Jul} 20$ ].

6. Kalcev G, Preti A, Orru G, Carta MG. Perinatal mental health: One of the biggest challenges in coronavirus disease- 19 crisis. Open Access Maced J Med Sci. 2020;8(1):245-7.

7. Bonari L, Pinto N, Ahn E, Einarson A, Steiner M, Koren G. Perinatal risks of untreated depression during pregnancy. Can J Psychiatry. 2004;49(11):726-35. https://doi. org/10.1177/070674370404901103

PMid:15633850

8. Littlewood E, Ali S, Ansell P, Dyson L, Gascoyne S, Hewitt C, et al. Identification of depression in women during pregnancy and the early postnatal period using the whooley questions and the Edinburgh postnatal depression scale. BMJ Open. 2016;6:1-9. https://doi.org/10.1136/bmjopen-2016-011223 PMid:27297012

9. O'Connor E, Rossom RC, Henninger M, Groom HC, Burda BU. Primary care screening for and treatment of depression in pregnant and postpartum women: Evidence report and systematic review for the US preventive services task force. J Am Med Assoc. 2016;315(4):388-406. https://doi.org/10.1001/ jama.2015.18948

PMid:26813212

10. Baron EC, Hanlon C, Mall S, Honikman S, Breuer E, Kathree T, et al. Maternal mental health in primary care in five low-and middle-income countries: A situational analysis. BMC Health Serv Res. 2016;16:53. http://doi.org/10.1186/s12913-016-1291-z PMid:26880075

11. Surjaningrum ER, Minas $\mathrm{H}$, Jorm AF, Kakuma R. The Feasibility of a role for community health workers in integrated mental health care for perinatal depression: A Qualitative study from Surabaya, Indonesia. Int J Ment Health Syst. 2018;12:27. https://doi.org/10.1186/s13033-018-0208-0

PMid:29881450

12. Rahman A, Surkan PJ, Cayetano CE, Rwagatare $P$, Dickson KE. Grand challenges: Integrating maternal mental health into maternal and child health programmes. PLoS Med. 2013;10(5):e1001442. http://doi.org/10.1371/journal. pmed.1001442 PMid:23667345

13. Arsenault $C$, Jordan K, Lee D, Dinsa G, Manzi F, Marchant T, et al. Equity in antenatal care quality: An analysis of 91 national household surveys. Lancet Glob Health. 2018;6(11):e1186-95. http://doi.org/10.1016/S2214-109X(18)30389-9

14. Noonan M, Doody O, Jomeen J, Galvin R. Midwives' perceptions and experiences of caring for women who experience perinatal mental health problems: an integrative review. Midwifery. 2017;45:56-71. http://doi.org/10.1016/j.midw.2016.12.010 PMid:28039845

15. Sorsdahl K, Petersen P. Feasibility and Preliminary Responses to a Screening and Brief Intervention Program for Maternal Mental Disorders Within the Context of Primary Care. Community Ment Health J. 2015;51(8):962-9. http://doi. org/10.1007/s10597-015-9853-9 PMid:25744699

16. Kementerian Kesehatan Republik Indonesia. Peraturan Menteri Kesehatan Republik Indonesia Nomor 97 Tahun 2014 tentang Pelayanan Kesehatan Masa Sebelum Hamil,Masa Hamil, Persalinan dan Masa Sesudah Melahirkan, Penyelenggaraan Pelayanan Kontrasepsi Serta Pelayanan Kesehatan Seksual. Jakarta, Indonesia: Kementerian Kesehatan Republik Indonesia; 2014. Available from: http://www.peraturan.go.id. [Last accessed on $2021 \mathrm{Jul} 01$ ].

17. He J, van de Vijver FJ. Choosing an adequate design and analysis in cross-cultural personality research. Curr Issues Personal Psychol. 2017;5(1):3-10. http://doi.org/10.5114/ cipp.2017.65824

18. ACOG committee opinion No. 757: Screening for perinatal depression. Obstet Gynecol. 2018;132(5):208-12. http://doi. org/10.1097/AOG.0000000000002927 PMid:30629567

19. Stewart RC, Umar E, Tomenson B, Creed F. Validation of screening tools for antenatal depression in Malawi-a comparison of the Edinburgh postnatal depression scale and self reporting questionnaire. J Affect Disord. 2013;150:1041-7. http://doi. org/10.1016/j.jad.2013.05.036 PMid:23769290

20. Van Heyningen T, Honikman S, Tomlinson M, Field S, Myer L. Comparison of mental health screening tools for detecting antenatal depression and anxiety disorders in South African women. PLoS One. 2018;10:1-18. https://doi.org/10.1371/ journal.pone. 0193697

PMid:29668725 
21. Ali GC, Ryan G, De Silva MJ. Validated screening tools for common mental disorders in low and middle income countries: A systematic review. PLoS One. 2016;11(6):e0156939. https:// doi.org/10.1371/journal.pone.0156939

PMid:27310297

22. Kendig S, Keats JP, Hoffman MC, Kay LB, MillerES, Simas TA, et al. Consensus bundle on maternal mental health: Perinatal depression and anxiety. J Midwifery Womens Health. 2017;62(2):232-9. https://doi.org/10.1097/AOG.0000000000001902 PMid:28178041

23. Cox JL, Holden JM, Sagovsky R. Detection of postnatal depression: Development of the 10-item Edinburgh postnatal depression scale. Br J Psychiatry. 1987;150:782-6. https://doi. org/10.1192/bjp.150.6.782

PMid:3651732

24. Department of Health, Australia Government of Western. Edinburgh Postnatal Depression Scale (EPDS): Translated Versions. State Perinatal Mental Health Reference Group, Western Australia. Australia: Department of Health, Australia Government of Western; 2006. p. 1-271.
25. Konicki C, lorio D. Measurement in Health Behavior: Methods for Research and Education. $1^{\text {st }}$ ed. United States: Jossey-Bass; 2005. p. 1-336.

26. Hair JF, Black WC, Babin BJ, Anderson RE. Multivariate Data Analysis. $7^{\text {th }}$ ed. United Kingdom: Pearson; 2014.

27. Tajudin M, Puteh M, Adnan M. Developing themes of guiding principles to foster higher order thinking skills in teaching and learning of mathematics. Int J Acad Res Progress Educ Dev. 2017;6(4):90-103.

28. Coates R, Ayers S, De Visser R. Factor structure of the Edinburgh postnatal depression scale in a population-based sample. Psychol Assess. 2017;29(8):1016-27. https://doi. org/10.1037/pas0000397 PMid:27736124

29. Marsay C, Manderson L, Subramaney U. Validation of the Whooley questions for antenatal depression and anxiety among low-income women in urban South Africa. South Afr J Psychiatry. 2017;23(1):1013. https://doi.org/10.4102/ sajpsychiatry.v23i0.1013

PMid:30263185 